Науковий вісник НлтУ України

Scientific Bulletin of UNFU

http://nv.nltu.edu.ua

https://doi.org/10.15421/40280202

Article received 22.03.2018 p.

Article accepted 29.03.2018 p.

удК 581.[4+9]:58.006:634.524
ISSN 1994-7836 (print)

ISSN 2519-2477 (online)

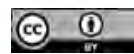

@ Correspondence author

T. B. Vakulenko

botanicukr@gmail.com

${ }^{1}$ Ботанічний сад ім акад О. В. Фоміна Киӥвського начіонального університету ім. Тараса ШНевченка, м. Киї, Україна

${ }^{2}$ Начіональний ботанічний сад ім. М. М. Гришка НАН Украӥни, м. Київ, Украӥна

\title{
ЗБЕРЕЖЕННЯ ЕХ SITU КИЗИЛЬНИКІВ ФЛОРИ СИБІРУ У БОТАНІЧНОМУ САДУ ІМ. АКАД. О. В. ФОМІНА КИЇВСЬКОГО НАЦІОНАЛЬНОГО УНІВЕРСИТЕТУ ІМ. ТАРАСА ШЕВЧЕНКА
}

Відзначено, що колекція видів роду Cotoneaster Medik. у ботанічному саду ім. акад. О. В. Фоміна Київського національного університету ім. Тараса Шевченка - найбільша у Східній Європі, налічує 200 видів та культиварів, серед яких кілька представників флори Сибіру: C. commixtus (C. K. Schneider) Flinck et Hylmo;; C. kyachticus, species nov.; C. laxiflorus Jacq. ex Lindl.; C. logginovii Grevtsova; C. lucidus Schlecht.; C. megalocarpus M. Popov.; C. mongolicus Pojark.; C. neo-popovii Czerepanov sp. nov.; C. tjulinae Pojark.; C. yacuticus J. Fryer et B. Hylmo. Зазначено, що C. kyachticus, sp. nov., який тривалий час у ботанічному саду культивовано під назвою C. melanocarpus Fisch.ex Blytt, після знайомства з гербарієм природних зборів Сибіру (м. Новосибірськ) виокремлено в інший таксон. Наведено детальний опис пагонів, листків, квіток, плодів та насіння інтродукованих кизильників сибірської флори, виділено діагностичні ознаки, що сприяють ідентифікації таксонів. Наголошено, що аналіз морфологічних ознак C. пео-ророvii та С. tjulinae дає всі підстави відновити ці види у списках флори Сибіру, 3 яких упродовж останнього часу вони вилучені. Встановлено, що на цей час в Ботанічному саду ім. акад. О. В. Фоміна Київського національного університету ім. Тараса Шевченка зберігається ex situ дев'ять видів Cotoneaster флори Сибіру та три форми міжродового гібриду $\times$ Sorbocotoneaster pozdnjakovii Pojark.

Ключові слова: інтродукція; морфологічні ознаки; щиток; гіпостиль.

Вступ. Наприкінці XX - початку XXI ст. інтродукція рослин стає основною ланкою збереження біологічного різноманіття в умовах ex situ. Багато зниклих та зникаючих видів знайшли притулок у ботанічних садах, дендраріях, альпінаріях, заказниках та заповідниках. Ботанічний сад ім. акад. О. В. Фоміна на території України став центром збереження представників роду Сotoneaster Medik. (Кизильник). Колекцію рослин створювали з 1972 р. за методом родових комплексів Ф. Н. Русанова (Rusanov, 1971), на сьогодні налічує 200 видів та культиварів і є найбільшою у Східній Свропі. Залучення вихідного матеріалу відбувалося шляхом виписки насіння за каталогами ботанічних садів та зборів насіння і живого матеріалу in situ (Grevtsova, 1999).

Ареал більшості видів Cotoneaster охоплює гірські райони Азії, Індії, Монголії, Китаю, Бірми, Непалу. За даними Жанет Фраєр і Бертил Гільмо (Fryer \& Hylmo, 2009), у світовій флорі поліморфний рід Cotoneaster представлений 462 таксонами, що належать до двох підродів (Chaenopetalum та Cotoneaster), 11 секцій та 37 серій. Дев'ять видів кизильників флори Сибіру належать до чотирьох секцій та чотирьох серій підроду Сotoneaster; і тільки один - C.multiflorus - до підроду Chaenopetalum, section Multiflori, series Multiflori.

У новітньому виданні "Древесные растения Азиат- ской России" (Koropachinskiy \& Vstovskaya, 2002) автори для флори Сибіру відзначають п'ять видів кизильників: C. lucidus Schlecht., C. megalocarpus M. Popov, C. melanocarpus Fisch.ex Blytt, C. multiflorus Bunge, C. uniflorus Bunge, а також акцентують увагу на тому, що немає серйозних підстав на цей час залишати у списку сибірських видів C. tjulinae Pojark., C. popovii Pojark., C. neo-popovii Czerepanov, C. mongolicus Pojark., оскільки вони потребують ретельнішого та всебічного вивчення.

Мета дослідження - проаналізувати морфологічні особливості пагонів, листків, квіток, плодів і насіння кизильників сибірської флори, інтродукованих до Ботанічного саду ім. акад. О. В. Фоміна, що забезпечить уточнення обсягу таксонів та виявлення нових їх діагностичних ознак.

Матеріали та методи дослідження. Для дослідження використано живі рослини, гербарні зразки, плоди і насіння інтродуцентів. Для опису морфологічних ознак застосовано загальноприйняту схему (Fedorov et al., 1956). Забарвлення морфологічних органів подано за шкалою кольорів А. С. Бондарцева (Bondartsev, 1954). Плоди та насіння фотографували за допомогою світлового мікроскопа Stemi-2000. Фотознімки рослин виконали О. Шевченко та Г. Гревцова.

\section{Інформація про авторів:}

Гревцова Галина Терентіївна, д-р біол. наук, професор, провідний науковий співробітник сектору.

Email: grevtsova_1940@ukr.net

Вакуленко Тетяна Борисівна, канд. біол. наук, ст. науковий співробітник відділу природної флори. Email: botanicukr@gmail.com Цитування за ДСтУ: Гревцова Г. Т., Вакуленко Т. Б. Збереження ех situ кизильників флори Сибіру у ботанічному саду ім. акад. О. В. Фоміна Київського національного університету ім. Тараса Шевченка. Науковий вісник НлТУ України. 2018, т. 28 , № 2. С. 20-25.

Citation APA: Grevtsova, H. T., \& Vakulenko, T. B. (2018). Maintenance of ex situ of Cotoneasters of Siberian Flora in Academic A. V. Fomin Botanical Garden of Taras Shevchenko National University of Kyiv. Scientific Bulletin of UNFU, 28(2), $20-25$.

https://doi.org/10.15421/40280202 
Результати дослідження та їх обговорення. Нижче наводимо описи морфологічної будови досліджених таксонів.

Section Cotoneaster, series Melanocarpi
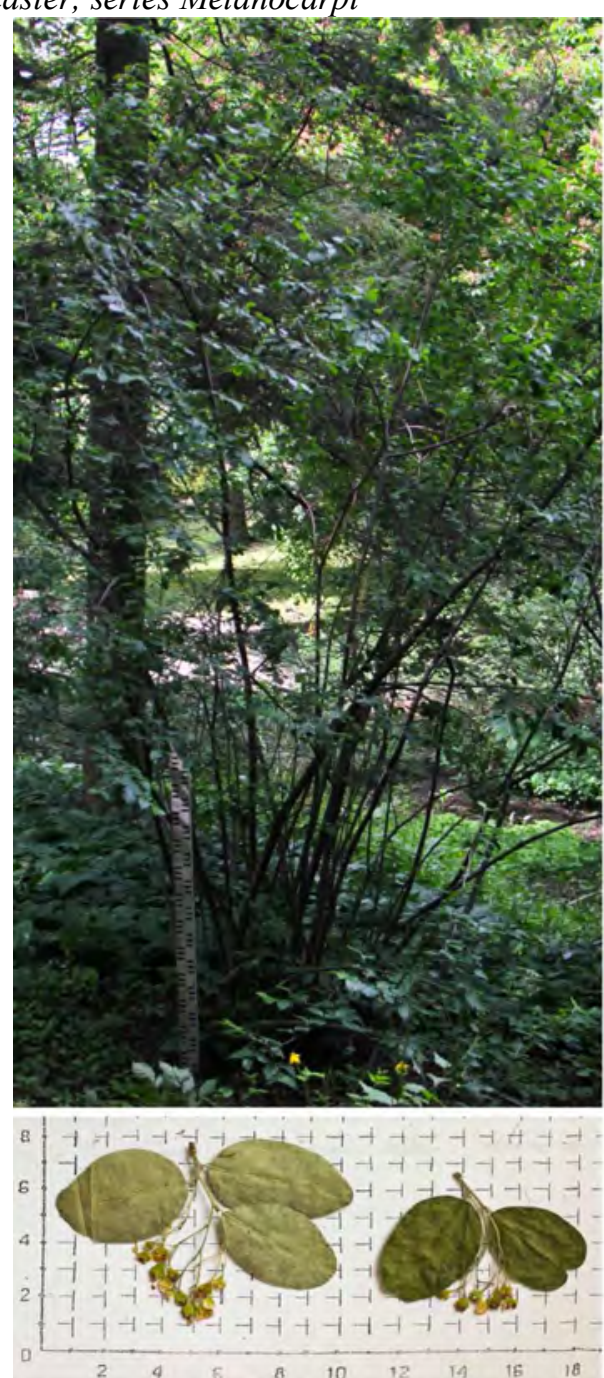

Рис. 1. Габітус Cotoneaster laxiflorus Jacq. ex Lindl.

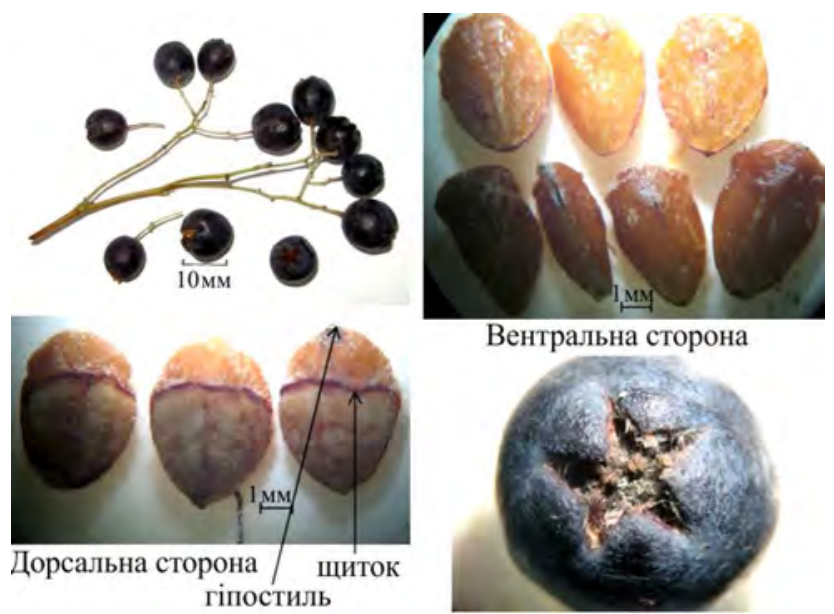

Рис. 2. Плоди та кісточки Cotoneaster laxiflorus Jacq. ex Lindl.

Пряморослий, ширококронний чагарник заввишки 3,5 м. Молоді пагони блакитно-зелені (и-5), повстяні, пізніше темно-зелені (м-4), волосисті, тьмяні. Однорічні пагони темно-оливкові (e-4) зі спадаючим білим нальотом; дворічні - брудно-фіолетові (м-3); трирічні темно-фіолетові (3-2). Листки яйцеподібні чи еліптичні, 28-50×20-27 мм, на стерильних пагонах ледь загострені, 50-70×35-45 мм; верхівка заокруглена, основа ши-
Cotoneaster laxiflorus Jacq. ex Lindl. - кизильник рихлоквітковий (рис. 1, 2). Вирощено з насіння рослин дендрарію Сторожинецького лісового технікуму (Україна), які завіз В. К. Терлецький із Сибіру.

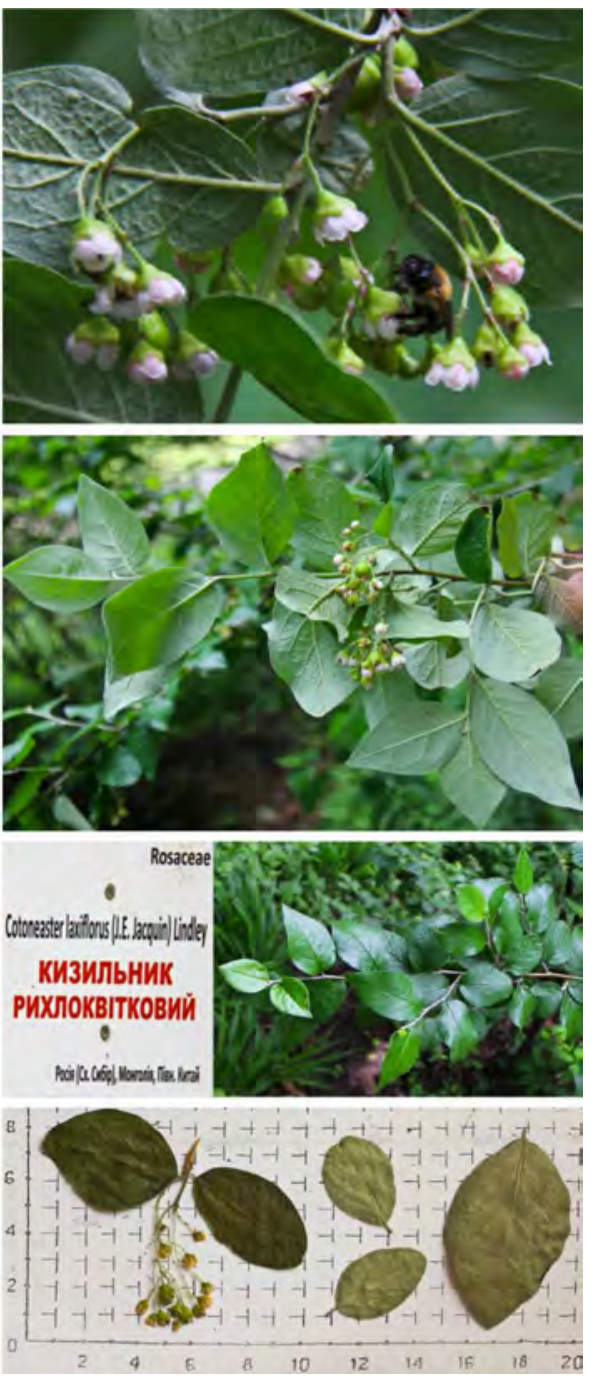

рокотрикутна. Забарвлення листків зверху темнотрав'янисто-зелене (м-4), з волосистою облямівкою, що пізніше зникає. Зісподу листки спочатку блакитні (л-4), далі синювато-сірі (и-3), щетинисто-волосисті, із виступаючою густо опушеною центральною жилкою та 4-ма парами бічних. Черешки завдовжки 3-6 мм, шетинистоволосисті. Прилистки шилоподібні, 4-6 мм завдовжки, фіолетово-кармінові, повстяні. Квітки у звисаючих волотеподібних суцвіттях у пазухах із 2-3-х листків або на кінцях гілочок. Суцвіття 13-15-квіткові із 3-х напівзонтиків. Квітконоси завдовжки 20-30 мм, квітконіжки - (7) 15-20 мм, волосисті. Віночок 4-6 мм у діаметрі, пелюстки рожеві, прямостоячі або ледь відхилені. Чашолистики широкотрикутні, заокруглені або гоструваті, голі. Тичинок (18) 20, тичинкові нитки та пиляки білі. Маточка із 2-3-х стовпчиків. Плоди округлі, у пониклих щитках, по (2-3) 5-8 (11), темно-пурпурові (г1), каштанові (к-4), сливово-чорні (о-1), 9-10×8-9 мм, тьмяні, голі; плодоноси завдовжки 10-15-20 мм, плодоніжки - 5-12 мм, 3 поодинокими плодами завдовжки 10-25 мм. Гіпантій не зрослий, із залишками тичинок, голий. Кісточок 2-3 (4), 5×4 мм, овальні, обернено яйцеподібні, на верхівці заокруглені, при основі заокруглені або широкотрикутні. Гіпостиль 3 дорсальної 
сторони оливково-зелений (3-1), бістровий (к-7), тьмяний, гладенький. Щиток займає $2 / 3$ або більше дорсальної сторони кісточки, випуклий, з поздовжньою асиметричною заглибиною; шкірясто-бурий (д-4), попелястосірий (к-2). Лінія розподілу щитка і гіпостилю чітка, гіпостиль нависає над щитком. Кісточки 3 вентральної сторони при двох кісточках плескуваті, з помітною центральною лінією та слабким виступом; при трьох кісточках - двогранні, з гладенькими боками і виступа- ючим ребром. Стовпчик прикріплений 3 вентральної сторони кісточки на відстані 1/4 iї довжини від верхівки. Плоди дозрівають у серпні.

Section Megalocarpi, series Megalocarpi

C. megalocarpus M. Popov - кизильник великоплодий (рис. 3,4$)$. Вирощений $з$ насіння рослин дендрарію Сторожинецького лісового технікуму (Україна), які завіз В. К. Терлецький із Сибіру.
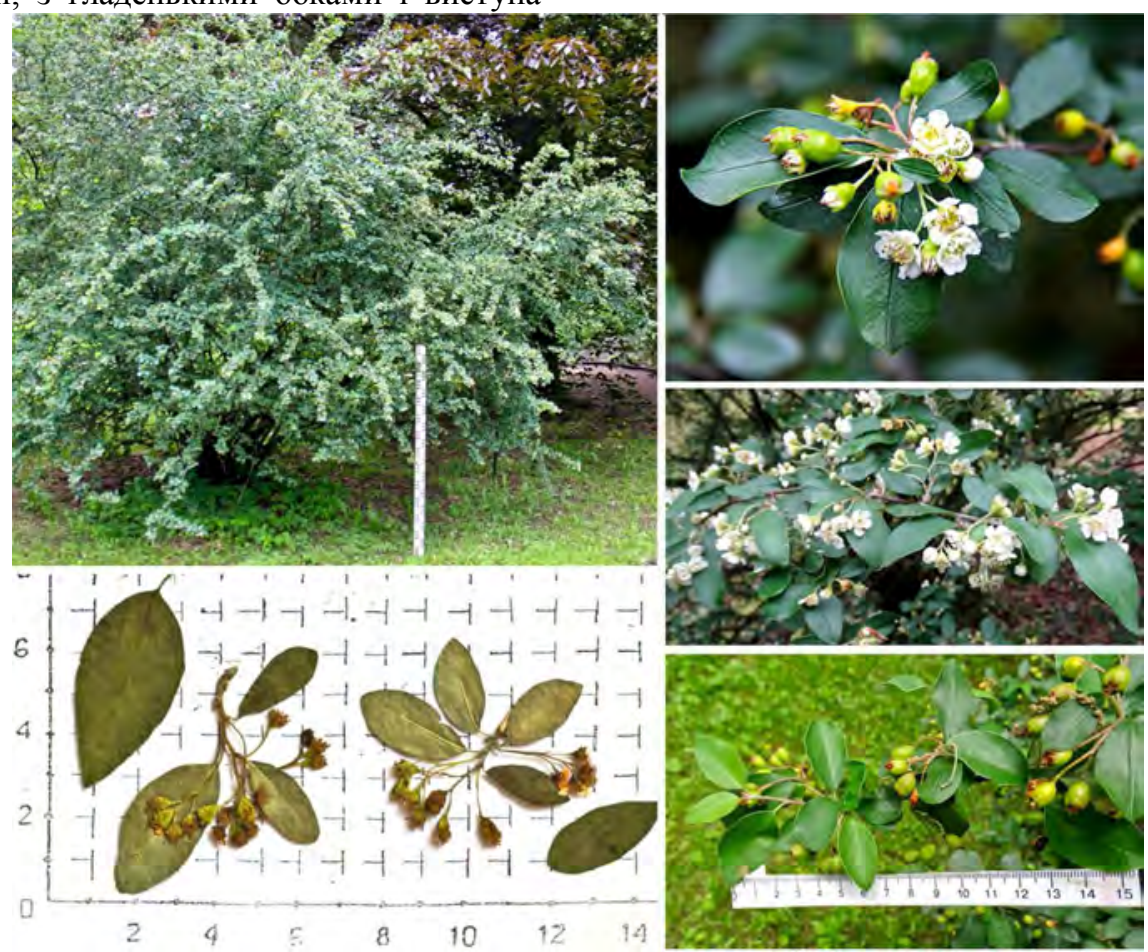

Pис. 3. Габітус Cotoneaster megalocarpus M. Popov
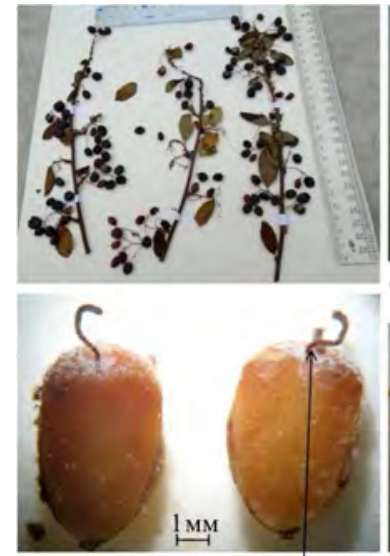

Вентральна сторона стовпчик
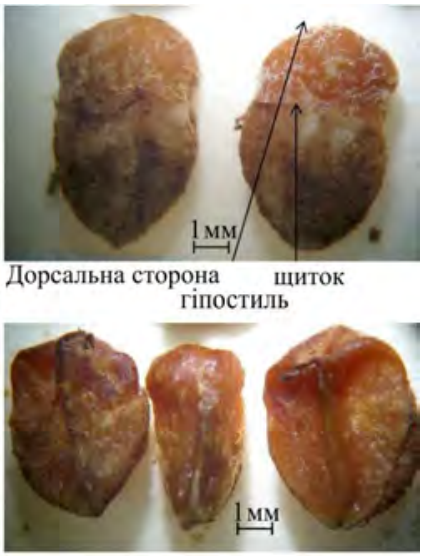

Рис. 4. Плоди та кісточки Cotoneaster megalocarpus M. Popov

Пряморослий, ширококронний, густогіллястий чагарник до 3,5 м заввишки. Молоді пагони жовто-зелені (б-3), повстяні, пізніше синювато-зелені (б-2).Однорічні пагони брудно-фіолетові (м-3), зі спадаючим білим нальотом; дворічні - темно-умброві (п-2), з рідкими білими чечевичками, трирічні - темно-сірі (a-2). Листки довгасто яйцеподібні, довгасто еліптичні, ромбовидно яйцеподібні, 22-33×7-12 мм, на стерильних пагонах загострено яйцеподібні, 30-55×17-36 мм; на верхівці часто 3 вістрям, біля основи заокруглені, клиноподібні, широкотрикутні; зверху оливково-зелені (3-1), спочатку волосисті, потім з рідкими волосками по центральній жилці; зісподу зелені (е-3), спочатку повстяні, потім зі слабким опушенням по центральній жилці і трьом па- рам слабопомітних бічних жилок. Черешки завдовжки 5-8 мм, густоволосисті. Прилистки шилоподібні, завдовжки 3 мм, опушені, фіолетово-кармінові. Квітки в горизонтально-розпростертих пониклих щитках. Суцвіття (1) 3-10 (17)-квіткові, у пазухах з трьох листків або на кінцях гілочок. Квітконоси завдовжки 10-20 мм, опушені, квітконіжки 7-10 (15) мм, з густішим опушенням. Віночок 7-10 мм в діаметрі, пелюстки рожево-білі, майже розпростерті, $3 \times 4$ мм. Чашолистки широкотрикутні, на верхівці з фіолетово-карміновою смугою, слабоопушені. Чашечка майже гола. Тичинок 13, тичинкові нитки та пиляки білі. Маточка із 1-2-х стовпчиків.

Плоди у щитках по (3) 4-7 (9), кіноварно-червоні (п7), фіолетово-кармінові (н-6), тьмяні або слабко лискучі 8-13×7-13 мм; плодоноси від 5 до 35 мм завдовжки. Гіпантій не зрослий, із залишками тичинок. Кісточок 2-3, овальні, обернено-яйцеподібні, 6×4 мм, на верхівці заокруглені, у основі заокруглені або широкотрикутні. Гіпостиль 3 дорсальної сторони оливково-жовтий (б-7), тьмяний, гладенький. Щиток займає $2 / 3$ дорсальної сторони кісточки, випуклий, з реберцем посередині; теракотовий (о-2), жовто-бурий (б-5). Лінія розрізу щитка і гіпостилю чітка, гіпостиль нависає над щитком. Кісточки з вентральної сторони при двох кісточках плескуваті iз помітним реберцем; при трьох кісточках - двогранні, бугристі, з виступаючим по центру ребром. Стовпчик кріпиться до верхівки кісточки. Плоди дозрівають у липні - на початку серпня.

Section Megalocarpi, series Megalocarpi

C. mongolicus Pojark. - кизильник монгольский (рис. 5, 6). 

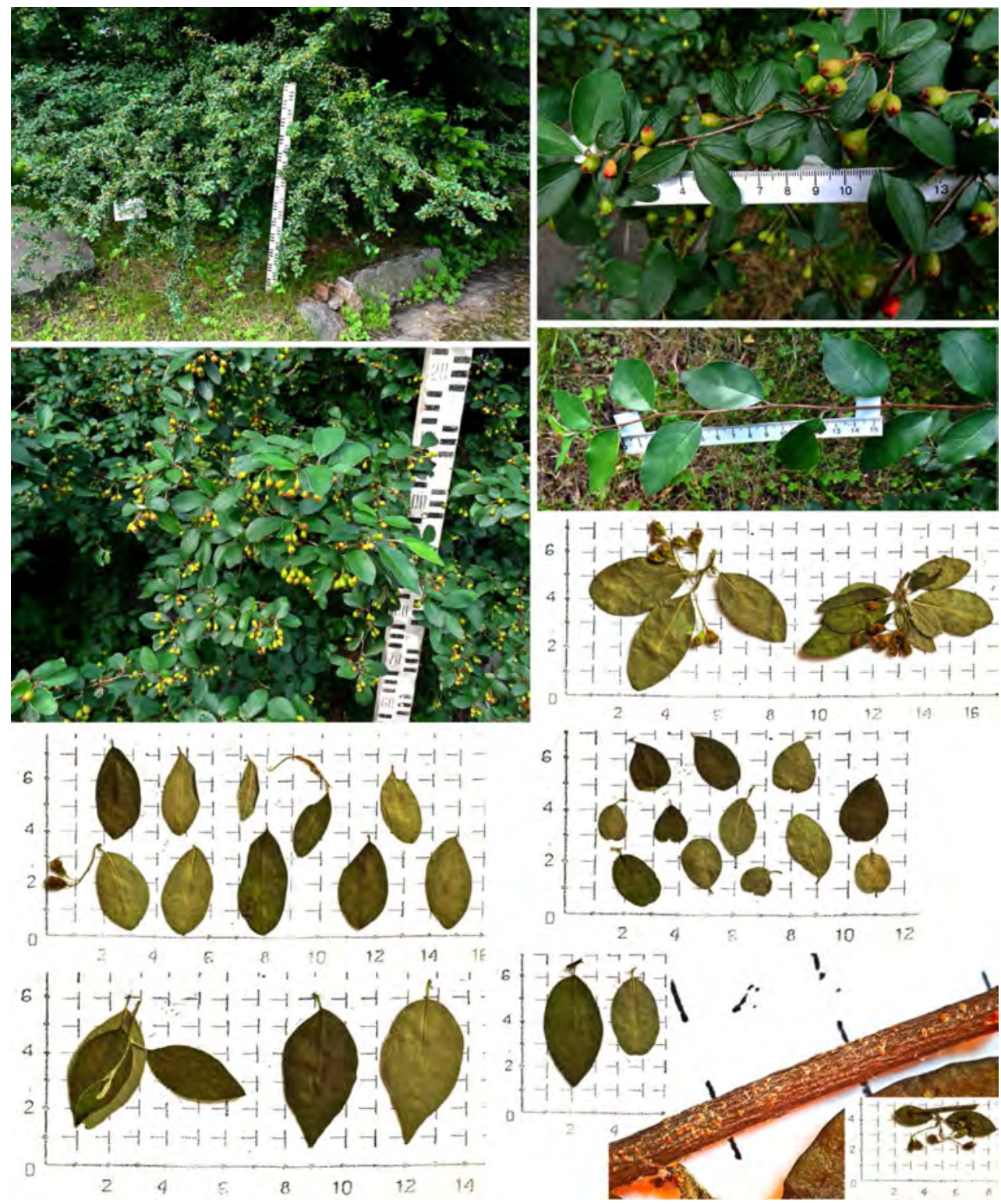

Pис. 5. Габітус Cotoneaster mongolicus Pojark.

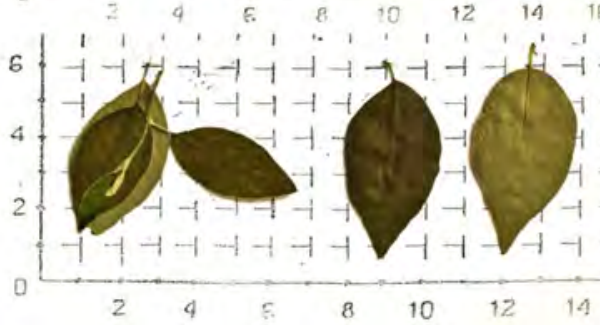

Привезено живою рослиною з Росії: Читинська обл., Борзінський р-н, о3. Зун-Бурун Торей (в 40 км від ст. Соловйовськ), в ущелинах скель, уздовж селевих потоків (15.08.1983 р.).

Пряморослий, слабогіллястий чагарник заввишки до 3 м. Молоді пагони блідо-бірюзові (а-7), повстисті, пізніше зверху темно-коричневі (л-5), знизу зелені, потім оголюються. Однорічні пагони брудно-фіолетові (м-3), зі спадаючим білим нальотом; дворічні - брудно-фіолетові (м-3), зрідка з білими чечевичками; трирічні - темно-умброві (п-2) з великою кількістю чечевичок. Більшість листків на фертильних пагонах ланцетоподібні, 25-37×9-19 мм, на верхівці заокруглені, іноді з вістрям, біля основи заокруглені або ширококлиноподібні; рідше трапляються листки яйцеподібні, широкояйцеподібні, 15-27×11-18 мм, округлі, 10×10 мм, на верхівці часто з виїмкою, біля основи заокруглені або ширококлиноподібні. На стерильних пагонах листки загострено яйцеподібні, 20-55×15-29 мм, зверху темно-зелені (ж7), по краю волосисті, потім голі. Зісподу молоді листки спочатку блідо-бірюзові (а-7), повстяні, згодом зеленоcipi (и-4), з рясним опушенням по центральній жилці та 3 4-ма парами слабопомітних бічних жилок. Черешки 2-5 мм, опушені. Прилистки шилоподібні, 3-4 мм, густоволосисті, фіолетово-кармінові. Квітки у горизон- тально-розпростертих та пониклих щитках. Суцвіття 69-квіткові, у пазухах з 2-7 листків, утворені двома напівзонтиками, обов'язково з одним бутоном на довгій осі. Квітконоси і квітконіжки завдовжки 5-15 мм, опушені. Віночок 7-10 мм в діаметрі.

Пелюстки рожево-білі, білі, $3 \times 4$ мм. Чашолистки широкотрикутні, чашечка гола. Тичинок 9 , тичинкові нитки та пиляки білі. Маточка із 1-2-х стовпчиків. Плоди у щитках по 3-5, округлі, округло еліптичні, еліптичні, 9-11×8-12 мм, кіноварно-червоні, фіолетово-кармінові, лискучі або тьмяні, голі; плодоноси завдовжки 7-10 мм, плодоніжки 5-13 мм (до 30 мм з поодинокими плодами). Гіпантій не зрослий, із залишками тичинок, голий.

Кісточок 1-2, 6×4 мм, обернено яйцеподібні, на верхівці заокруглені, у основі широкотрикутні. Гіпостиль 3 дорсальної сторони червонувато-бурий (3-5), коричневий (б-7), тьмяний, гладенький. Щиток займає більше $2 / 3$ дорсальної сторони кісточки, випуклий, із виступаючим по центру реберцем, рідше з поздовжньою заглибиною, шкірясто-бурий (д-4), попелястий (к-2). Лінія розподілу щитка і гіпостилю чітка. Гіпостиль нависає над щитком. Кісточки з вентральної сторони плескуваті, з поздовжніми виступаючими реберцями. Стовпчик кріпиться до верхівки кісточки. Плоди дозрівають у серпні. 


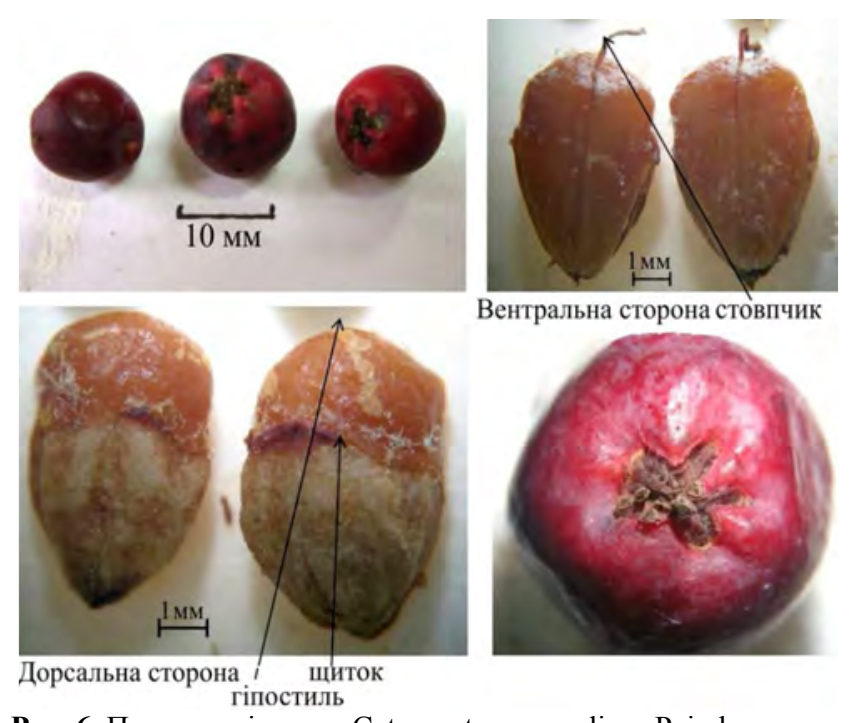

Рис. 6. Плоди та кісточки Cotoneaster mongolicus Pojark

\section{Section Cotoneaster, Series Melanocarpi}

Cotoneaster neo-popovii Czerepanov - кизильник Попова новий. Привезено живою рослиною 3 Росії: Іркутська обл., сел. Ліственічноє (порт Ліствянка), по вул. Куликова в 1,5 км від селища, зліва від болота, у сосново-модриновому лісі, біля гори Крестовая (10.08.1983 р.)

Пряморослий, широкогіллястий чагарник заввишки 3,5 м. Молоді пагони жовто-зелені (б-3), повстяні, потім трав'янисто-зелені (л-4), густо-волосисті; однорічні - темно-оливкові (е-4), зі спадаючим білим нальотом та коричневими чечевичками; дворічні - сливово-чорні (о1); трирічні - темно-каштанові (о-7). Листки еліптичні, яйцеподібні, загострено еліптичні, 30-48×20-29 мм, на стерильних пагонах загострено еліптичні, обернено яйцеподібні, еліптичні, 50-75×27-35 мм; на верхівці заокруглені, рідко виїмчасті, загострені, з вістрям або без; біля основи заокруглені; зверху зелено-малахітові (и-7), голі; зісподу зелені (е-5), щетинисто-волосисті, з виступаючою повстяною центральною жилкою та 3 (4)-ма парами бічних жилок. Черешки 3-5 мм, густоволосисті. Прилистки шилоподібні, 4-6 мм, фіолетово-кармінові, густоволосисті. Квітки у звисаючих волотеподібних суцвіттях, у пазухах з 2-3-х листків або на гілочках завдовжки 10 мм. Суцвіття 9-15-квіткові, з трьох напівзонтиків. Квітконоси 30-45 мм, квітконіжки 10-15 мм, спочатку опушені, потім голі. Віночок 5-7 мм у діаметрі, пелюстки рожеві, прямостоячі, округлі, $2 \times 2,5$ мм, без нігтика. Чашолистки широкотрикутні, 3 карміновою плямою на верхівці, чашечка спочатку опушена, потім гола. Тичинок 17-20, тичинкові нитки білі, пиляки жовтуваті. Маточка з 3-4-х стовпчиків.

Плоди у щитках, округлі, яйцеподібні, по 2 -5-7, діаметром 9-10 мм, темно-умброві (г-1), темно-каштанові (к-4), із сизим нальотом, лискучі або тьмяні. Плодоноси завдовжки 10-40 мм, плодоніжки 10-25 мм. Гіпантій не зрослий, із залишками тичинок, голий. Кісточок 2-3, $5 \times 4$ мм; обернено яйцеподібні та двогранні при трьох кісточках. Гіпостиль $з$ дорсальної сторони коричневобурий (в-2), гладенький, лискучий. Щиток займає $2 / 3$ дорсальної сторони, часто з помітною борозенкою по центру, буруватий (б-4), горіховий (к-5), восково-жовтий (3-3). Лінія розподілу гіпостилю та щитка чітка. Характер вентральної поверхні залежить від кількості кісточок у плоді. При двох кісточках - вентральна поверхня однієї має виступи, іншої - виїмки. При трьох кіс- точках - бокові поверхні ледь випуклі або виїмчасті, із чітким ребром. Стовпчик прикріплений з вентральної сторони кісточки на відстані 1/3 iї довжини від верхівки. Плоди дозрівають у другій половині липня.

Окрім описаних вище, у колекції зростає багато видів, привезених з місць природного зростання кизильників у Сибіру, куди було здійснено дві експедиції: перша (Якутська) у 1982 р. (10.08-29.08) за маршрутом: Київ - Новосибірськ - Іркутськ - Томськ - Красноярськ - Алдан - Томмот - Алдан - Іркутськ - Київ; друга (Центрально-Сибірська) у 1983 р. (24.07-17.08) за маршрутом: Київ - Іркутськ - Давша - Нижнє-Ангарськ Сєверо-Байкальск - Улан-Уде - Кяхта - Іркутськ - Чита- Москва - Київ.

C. commixtus (C. K. Schneider) Flinck et Hylmo - кизильник змішаний. Привезено живими рослинами з Бурятії: м. Кяхта, околиці міста, біля пивзаводу (06.08.1983 p).

C. kyachticus, species nov. - кизильник кяхтинський. Привезено живою рослиною з Бурятії: м. Кяхта, околиці міста, біля пивзаводу (06.08.1983 р.).

C. logginovii Grevtsova, sp. nov. - кизильник Логгінова (Grevtsova, 2015). Привезено живою рослиною 3 Росії: Читинська обл., Борзинський р-н, оз. Зун-Бурун-Торей (в 40 км від ст. Соловйовськ, в ущелинах скель, викопаний з-під материнської рослини C. mongolicus (15.08. 1983 p.).

Cotoneaster tjulinae Pojark. - кизильник Тюлиної.

Привезено живими рослинами з Бурятії: м НижньоАнгарськ, 8-10-й км по трасі на Північно-Байкальск, скелі за насипом БАМ, після покажчика "Магістральні тунелі", південний схил, степова ділянка (03.08.1983 р).

Cotoneaster yacuticus J. Fryer et B. Hylmo - кизильник якутський. Привезено живою рослиною з Якутії: м Алдан - Томмот, 102 км вниз за течією по р. Алдан, сопка вище Гольцевого поясу, у сосновому рідколіссі (20.08.1982 p.).

Окрім цього, у колекції зростають рослини міжродового гібриду $\times$ Sorbocotoneaster pozdnjakovii Pojark (горобинокизильника Позднякова), привезеного з Якутської експедиції у 1982 р. (Grevtsova et al., 2015) та Cotoneaster lucidus Schlecht. (кизильник блискучий), вирощений $з$ насіння рослин дендрарію Сторожинецького лісового технікуму (Україна), який завіз В. К. Терлецький із Сибіру.

Варто зазначити, що C. kyachticus, sp. nov. тривалий час у Ботанічному саду був під назвою C. melanocarpus. Проте після знайомства з гербарієм природних зборів Сибіру у Гербарії ім. М. Попова (м. Новосибірськ) з'явилися підстави для виокремлення цього зразка в інший таксон. Опис цього зразка надіслано до матеріалів міжнародної конференції "Проблемы ботаники Южной Сибири и Монголии" (Барнаул, 2018).

\section{Висновки}

1. На основі порівняльного аналізу морфологічних ознак досліджених кизильників вважаємо, що Cotoneaster neo-popovii та C. tjulinae мають всі підстави для перебування у списках флори Сибіру.

2. На цей час у Ботанічному саду ім. акад. О. В. Фоміна Київського національного університету ім. Тараса Шевченка зберігається ex situ дев'ять видів Cotoneaster флори Сибіру та три форми міжродового гібриду $\times$ Sorbocotoneaster pozdnjakovii Pojark.

Щиро дякуємо за допомогу і консультації директору Іркутського ботанічного саду Бєловежець Галині Пет- 
рівні, співробітникам Баргузинського заповідника: Федоровій Марії Олександрівні, Троїцькійї Наталії Іванівні, Чернікіну Свгену Михайловичу, Чернікіній Людмилі Дмитрівні; Шунковій Зінаїді Григорівні (Улан-Уде). Особлива подяка студентці географічного факультету Київського державного університету ім. Тараса Шевченка Гревцовій Наталії В'ячеславівні за розділені тяготи надзвичайно важкої подорожі 1983 р.

\section{Перелік використаних джерел}

Bondartsev, A. S. (1954). Scale of colors. Moscow-Leningrad: Publishing House of the Academy of Sciences of the USSR. 28 p. [in Russian].

Fedorov, Al. L., Kirpichnikov, M. E., \& Artiushenko Z. T. (1956). Atlas on descriptive morphology of higher plants. Sheet. Moscow-Leningrad: Publishing House of the Academy of Sciences of the USSR. 302 p. [in Russian].
Fryer, J., \& Hylmo, B. (2009). A Comprehensive Guide to Shrubs for Flowers, Fruit and Foliage. London-Portland: Timber Press. 344 p. Grevtsova, H. T. (1999). Atlas Coppersmiths Cotoneaster (Medic.) Bauhin. Kyiv: Home, garden, garden. 372 p. [in Russian].

Grevtsova, H. T. (2015). The cotoneaster Logginov is a new species of Cotoneaster for the flora of Southern Siberia. Problems of botany of Southern Siberia and Mongolia. Collection of scientific articles on the materials of the Fourteenth International Scientific and Practical Conference, (pp. 135-139), May 25-29, Barnaul. [in Russian].

Grevtsova, H. T., Vakulenko, T. B., \& Mikhaylova, I. S. (2015). Ex situ conservation of $x$ Sorbocotoneaster pozdnjakovii Poyark. In the Academic Fomin Botanical Garden. Agrobiodiversity for improving nutrition, health and life quality. Part I. Nitra. (pp. 196-200). [in Ukrainian]

Koropachinskiy, I. Yu., \& Vstovskaya, T. N. (2002). Cotoneaster Medic. Cotoneaster. Woody plants of Asian Russia, (pp. 310-316). Novosibirsk: Izdatel'stvo SB RAS, Geo. [in Russian].

Rusanov, F. N. (1971). The method of generic complexes in the introduction of plants. Bulletin GBS AN USSR, 81, 15-20. [in Russian].

Г. Т. Гревцова ${ }^{1}$, Т. Б. Вакуленко ${ }^{2}$

${ }^{1}$ Ботанический сад им. акад. О. В. Фомина Киевского начионального университета им. Тараса Шевченко, г. Киев, Украина ${ }^{2}$ Начиональный ботанический сад им. Н. Н. Гришко НАН Украины, г. Киев, Украина

\section{СОХРАНЕНИЕ ЕХ SITU КИЗИЛЬНИКОВ ФЛОРЫ СИБИРИ В БОТАНИЧЕСКОМ САДУ ИМ. АКАД. А. В. ФОМИНА КИЕВСКОГО НАЦИОНАЛЬНОГО УНИВЕРСИТЕТА ИМЕНИ ТАРАСА ШЕВЧЕНКО}

Отмечено, что коллекция видов рода Cotoneaster Medik. в ботаническом саду им. акад. О. В. Фомина Киевского национального университета им. Тараса Шевченко - наибольшая в Восточной Европе, насчитывает 200 видов и культиваров, среди которых несколько представителей флоры Сибири: C. commixtus (C. K. Schneider) Flinck et Hylmo;; C. kyachticus, species nov.; C. laxiflorus Jacq. ex Lindl.; C. logginovii Grevtsova; C. lucidus Schlecht.; C. megalocarpus M. Popov.; C. mongolicus Pojark.; C. neo-popovii Czerepanov sp. nov.; C. tjulinae Pojark.; C. yacuticus J. Fryer et B. Нylmo. Указано, что C. kyachticus sp. nov., который длительное время в ботаническом саду культивировался под названием C. melanocarpus Fisch.ex Blytt, после знакомства с гербарием природных сборов Сибири (г. Новосибирск) выделен в другой таксон. Приведено детальное описание побегов, листьев, цветков, плодов и семян интродуцированных кизильников сибирской флоры, выделены диагностические признаки, которые способствуют идентификации таксонов. Подчеркнуто, что анализ морфологических признаков $C$. neo-popovii и C. tjulinae дает все основания восстановить эти виды в списках флоры Сибири, откуда они в последнее время изъяты. Отмечено, что в настоящее время в Ботаническом саду им. акад. О. В. Фомина Киевского национального университета имени Тараса Шевченко сохраняется ex situ девять видов Cotoneaster флоры Сибири и три формы межродового гибрида $\times$ Sorbocotoneaster pozdnjakovii Pojark.

Ключевые слова: интродукция; морфологические признаки; щиток; гипостиль.

H. T. Grevtsova ${ }^{1}$, T. B. Vakulenko ${ }^{2}$

${ }^{1}$ The Academic Fomin Botanical Gardens of the Kyiv National Taras Shevchenko University, Kyiv, Ukraine ${ }^{2}$ M. M. Gryshko National botanical garden, NAS Ukraine, Kyiv, Ukraine

\section{MAINTENANCE OF EX SITU OF COTONEASTERS OF SIBERIAN FLORA IN ACADEMIC A. V. FOMIN BOTANICAL GARDEN OF TARAS SHEVCHENKO NATIONAL UNIVERSITY OF KYIV}

The collection of representatives of the genus Cotoneaster Medik. in A. V. Fomin Botanical Garden of Taras Shevchenko National University of Kyiv has been developed since 1972 based on the method of generic complexes. Today the collection comprises 200 species and cultivars and is the largest one in Eastern Europe. The source material was obtained due to extracting seeds from the catalogues of botanical gardens. Moreover, two expeditions were carried out to the place of natural growth of cotoneasters in Siberia, in 1982 and 1983. In world flora, the cotoneaster polymorphic genus is represented by 462 taxa belonging to two subgenus (Chaenopetalum and Cotoneaster), 11 sections and 37 series. Nine species of cotoneaster flora of Siberia are located in four sections and four series of cotoneaster subgenus; and only one (C. multiflorus) belongs to the subgenus Chaenopetalum, Section Multiflori, Series Multiflori. There are five species of cotoneaster in the latest studies of the Siberian flora: C. lucidus Schlecht., C. megalocarpus M. Popov, C. melanocarpus Fisch. ex Blytt, C. multiflorus Bunge, C. uniflorus Bunge. Cotoneaster tjulinae Pojark., C. popovii Pojark., C. neo-popovii Czerepanov, $C$. mongolicus Pojark were removed from the list of the Siberian species because they require a more thorough and comprehensive study. The authors conducted the analysis of the morphological characteristics of shoots, leaves, flowers, fruits, and seeds of cotoneasters of the Siberian flora, introduced in A. V. Fomin Botanical Garden in order to clarify the volume of taxa and identify new diagnostic features. A common scheme was used to describe the morphological features. As a result, the study suggested a detailed description of the shoots, leaves, flowers, fruits and seeds of the introduced Siberian floral cotoneasters. Moreover, the study outlines the diagnostic features that facilitate identifying the taxa. The research indicates that $C$. kyachticus, sp. nov., which has been cultivated for a long time in the botanical garden under the name $C$. melanocarpus, is isolated in another taxon after the detailed study of the herbarium of natural assemblies of Siberia (Novosibirsk). Consequently, the analysis of the morphological features of C. neo-popovii and C. tjulinae provides all grounds for the restoration of these species in the lists of Siberian flora. The study reveals that nine species of cotoneaster flora of Siberia and three forms of the interbred hybrid $\times$ Sorbocotoneaster pozdnjakovii Pojark are now preserved ex situ in A. V. Fomin Botanical Garden of Taras Shevchenko National University of Kyiv, Kyiv.

Keywords: introduction; morphological features; shield; hypostyle. 